\title{
GESTATIONAL WEIGHT GAIN AND NUTRITIONAL STATE OF THE NEWBORN: A DESCRIPTIVE STUDY
}

\author{
Kelen Cristina Ramos dos SANTOS ${ }^{a}$, Luana Oliveira MURARO \\ Maria Carolina WITKOWSKI ${ }^{\mathrm{c}}$, Márcia Koja BREIGEIRON ${ }^{\mathrm{d}}$
}

\begin{abstract}
The objective was to characterize puerperal women in relation to gestational weight gain and their newborns in accordance with the nutritional state at birth. This is a descriptive, quantitative and retrospective study approved by the Ethics Committee at the institution responsible. The collection of data was from December 2012 to May 2013. The sample was composed of 24 puerperal women and their children. The participants presented an average age of $26.5(\mathrm{DP}=5.4$ ) years, $79.2 \%$ white; $91.7 \%$ married; $58.3 \%$ multiparous; $75 \%$ with a level of education between secondary school and higher education; $58.3 \%$ with a low family income; $54.1 \%$ presented an altered pre-gestational nutritional state and $75 \%$ obtained an inadequate gestational weight gain. $79.2 \%$ of the newborns were classified as Adequate for Gestational Age (AIG). The newborns classified as Large for Gestational Age (GIG) were from pregnant women that had excessive weight gain or were overweight. It was concluded that health professionals should be attentive to nutritional deviations with the intention of avoiding complications for maternal/fetal health.
\end{abstract}

Descriptors: Nutritional state. Pregnancy. Birth weight.

\section{RESUMO}

O objetivo foi caracterizar puérperas quanto ao ganho de peso gestacional e seus neonatos conforme estado nutricional de nascimento. Consiste em estudo descritivo, quantitativo, retrospectivo, aprovado pelo comitê de ética da instituição responsável. A coleta dos dados foi de dezembro de 2012 a maio de 2013. A amostra foi de 24 puérperas e seus filhos. As puérperas apresentaram: média de idade de 26,5 (DP=5,4) anos, 79,2\% cor branca; 91,7\% casadas; 58,3\% multíparas; 75\% com escolaridade entre ensino médio e superior; $58,3 \%$ em situação de baixa renda familiar; $54,1 \%$ apresentaram estado nutricional pré-gestacional alterado e $75 \%$ obtiveram ganho ponderal gestacional inadequado. Dos neonatos, 79,2\% foram classificados como Adequados para a Idade Gestacional (AIG). Os neonatos Grandes para a Idade Gestacional (GIG) foram de gestantes com ganho ponderal excessivo ou com sobrepeso. Conclui-se que os profissionais de saúde devem estar atentos aos desvios nutricionais, com o intuito de evitar agravos à saúde materna/fetal.

Descritores: Estado nutricional. Gravidez. Peso ao nascer.

Título: Ganho de peso gestacional e estado nutricional do neonato: um estudo descritivo.

\section{RESUMEN}

El objetivo fue caracterizar las puérperas sobre el aumento de peso gestacional y sus hijos recién nacidos, como estado nutricional de nacimiento. Estudio descriptivo, cuantitativo, retrospectivo, aprobado por la Comité de Ética de la institución responsable. La recolección de datos fue entre diciembre 2012/mayo 2013. La muestra estuvo conformada por 24 madres y sus hijos. Las mujeres mostraron: promedio de edad de 26,5 (SD = 5,4) años, 79,2\% blancos, 91,7\% casadas o viven en pareja, 58,3\% multíparas, 75\% educación entre escuela y universidad, 58,3\% una situación de bajos ingresos; 54,1\% tenía antes del embarazo estado nutricional cambiado, 75\% tenía inadecuada ganancia de peso. 79,2\% de los recién nacidos se clasificaron como adecuado para edad gestacional/AIG. Los neonatos grandes para edad gestacional/GIG fueron de mujeres embarazadas con ganancia excesiva o sobrepeso. Se concluye que los profesionales de la salud deben ser conscientes de problemas nutricionales para evitar daños a la salud materna/fetal.

Descriptores: Estado nutricional. Embarazo. Peso al nacer.

Título: Ganancia de peso gestacional y estado nutricional de neonatos: un estudio descriptivo.

a Nurse, graduate of the Federal University of Rio Grande do Sul (RS), Brazil. E-mail: kelencrs@ibest.com.br

b Nurse, graduate of the Federal University of Rio Grande do Sul (RS), Brazil. E-mail: lua.muraro@gmail.com

c Nurse. Master of Health Sciences: Cardiology. Auxiliary nurse and preceptor of the Integrated Multi-professional Residency in Health (RIMS) at the Hospital de Clínicas de Porto Alegre/RS, Brazil. E-mail: mariacarolinawit@hotmail.com

d Nurse. Doctor of Biological Sciences: Physiology. Associate Professors at the UFRGS Nursing School. Assistant Professors at the Pediatric Nursing Service (SEPED) at the Hospital de Clínicas de Porto Alegre/RS, Brazil. E-mail: mbreigeiron@gmail.com 


\section{INTRODUCTION}

The prevalence of excess weight and obesity has become a large problem for public health ${ }^{(1)}$. In Brazil, the number of children diagnosed as being overweight or obese is growing. According to data from the National Demography and Health Survey in 2006 in Brazil excess weight in relation to height was found in $7 \%$ of children under five years, varying to $9 \%$ in the South Region ${ }^{(2)}$.

This preoccupying situation has led to concern about possible resultant factors. Previous studies have demonstrated the existence of a direct, significant association between weight gain during pregnancy and the nutritional state of children ${ }^{(3-4)}$. Therefore, maternal obesity would be an important indicator of childhood obesity, and could result in various prejudicial effects to maternal and fetal health.

Pregnancy is a period in which a woman's body undergoes intense physiological changes in order to enable the adequate growth and development of the fetus. As such, weight gain is a natural event during pregnancy and results from an increase in maternal tissues and products of conception. In addition to physiological factors, weight gain during pregnancy is also associated with nutritional, social and demographical, obstetric and behavioral factors ${ }^{(5)}$.

Despite being necessary, when excessive or insufficient, gestational weight gain can lead to negative consequences in the health of the woman or child. In this perspective, the Institute of Medicine of the National Academies (IOM-USA) ${ }^{(6)}$ recommends the total adequate gestational weight gain in accordance with the pre-gestational Body Mass Index (BMI). While there is no Brazilian reference curve with BMI values by gestational age, the Brazilian Ministry of Health uses the table elaborated by Atalah ${ }^{(7)}$ as a basis, which was constructed for the pregnant population of Chile. This table enables the nutritional state of the pregnant woman to be evaluated and diagnosed as expressed by the BMI values per gestational week.

Birth weight consists of the result of intrauterine growth and represents a marker of the nutritional tendency. In this sense, inadequate weight gain during pregnancy may influence fetal growth, causing alterations to the nutritional state of the newborn $^{(3,8)}$. Furthermore, the weight and health of the newborns are considered as determinant factors for growth and development during the first years of life ${ }^{(9)}$.

To evaluate the adequacy of bodyweight and stature in relation to gestational age the Ministry of Health uses the intrauterine growth curve elaborated by Margotto ${ }^{(10)}$. According with the percentiles, the birth weight curve classifies the newborn as small for gestational age (PIG), adequate for gestational age (AIG) and large for gestational age (GIG).

Therefore, as obesity is a problem for public health, it becomes relevant for nurses and other professionals to understand the factors involved in this outcome, enabling the planning of preventive and therapeutic strategies through qualified assistance to the pregnant woman.

In this perspective, the present study has the objective of characterize puerperal women in relation to gestational weight gain and the social and demographic aspects, as well as categorizing newborns in accordance with nutritional state at birth. As such, the hypothesis of this study is that inadequate gestational weight gain may alter the nutritional state of the newborn at birth.

\section{METHODS}

This is a transversal, retrospective and quantities study.

The study was realized at the Obstetric Hospitalization Unit (UIO) at a University Hospital (UH) located in the city of Porto Alegre/RS. This unit has 44 beds distributed in 13 rooms (5 wards, 2 private rooms and 6 semi-private rooms) and provides healthcare to pregnant and puerperal women and newborns. Furthermore, it is a reference for high risk pregnancies.

The sample was constituted of 24 puerperal women hospitalized at the UIO who had their prenatal consultations at a determined Basic Health Unit (UBS) in the same city, and their children were born at the Obstetric Center at the said UH. The selection of the sample in this study occurred in accordance with spontaneous demand, i.e. by convenience. In relation to the time period, the data collection period was from December 2012 to May 2013.

The following criteria were used for inclusion in the study: being aged 18 or over; being registered 
at the UBS and referred to the UH; having started obstetric monitoring at the UBS at least in the second trimester of the pregnancy. The exclusion criteria were having been diagnosed with comorbidities (previous or gestational diabetes mellitus, systemic arterial hypertension, heart problems, chronic respiratory diseases and HIV) and having a high risk pregnancy.

The criterion for inclusion of the child was birth to term. The exclusion criteria were: Apgar below seven in the fifth minute of life, diagnosis of congenital morbidities and malformations (such as gastroschisis, omphalocele, myelomeningocele, serious cardiac malformations or other requiring surgical correction or resulting in death).

The puerperal women selected that fulfilled the inclusion criteria were invited to participate in the study on the $2^{\text {nd }}$ day postpartum, still at the UIO. This moment was followed by signing the Declaration of Free and Clarified consent and, the first part of the instrument for data collection was applied using an interview with closed questions related to the demographic and socioeconomic aspects. In the second part of the instrument for data collection, the researcher recorded prenatal and birth related information, collected from the medical records at the $\mathrm{UH}$.

Considering the occurrence of physiological postural alterations during pregnancy, the height measurement used for calculation of the BMI was that recorded on the prenatal records at the start of the pregnancy. The anthropometric measurements of the women were collected from the prenatal records and the vital sign record sheet at the hospital institution. The anthropometric data of the newborn were collected from the electronic records or the vital sign record sheet. For defining the gestational age, the value used was that obtained using the Capurro method realized by the neonatology nurse present at the time of admission of the newborn at the UH obstetric center.

In relation to the data analysis, the variables relating to the pregnancy were: maternal BMI, monthly home income per capital and the number of consultations in the prenatal period. The variables relating to the newborn were weight and length at birth and gestational age.

The data collected was organized and codified manually in the instruments. After this stage the data was recorded in the database using the
Statistical Package for Social Sciences (SPSS) version 18.0, with double data entry used for early detection of possible errors in the tabulation in order to correct them. The data was analyzed using descriptive statistics in which the discrete variables were presented using the average and standard deviation from the average. The categorical variables were presented in according with the absolute and relative frequency.

In relation to the pre-gestational BMI the women were classified as low weight, eutrophic, overweight or obese according to the IOM-USA. In relation to gestational weight gain, they were classified as insufficient, adequate or excessive weight gain, in accordance with the recommendations of the IOM-USA. For classification of the nutritional state of the pregnant woman at the time of admission to the hospital the Atalah ${ }^{(7)}$ table was used. The newborns were classified in relation to the weight and stature measurements in accordance with gestational age, based on the graphs by Margotto(10).

This study was approved by the Research Commission at the Federal University of Rio Grande do Sul Nursing School (COMPESQ/ EENF UFRGS) and by the Ethics and Research Committee at the institution responsible, under number 75433 .

The participants in the study received a copy of the Declaration of Free and Clarified Consent that contained information in relation to the reliability of the data and possible withdrawal at any stage of the study.

The study followed the bioethical aspects in accordance with National Health Council Resolution $n^{\text {o }} 466$, December $12^{\text {th }} 2012^{(11)}$.

\section{RESULTS}

The characteristics of the sample studied in relation to the social, demographic and economic aspects are given in Table 1. The characteristics in relation to nutritional state and gestation are described in Table 2.

The data encountered in this study characterizes the majority of the participants as young, white, multiparous women that were married or living with a partner.

In relation to maternal level of education, it was noted that the majority of participants had completed primary and secondary education, and 
Table 1 - Characteristics of the sample studied in relation to the social, demographic and economic aspects - Porto Alegre, 2013.

\begin{tabular}{lcc}
\hline \multicolumn{1}{c}{ Variables } & $\mathbf{n}(\mathbf{2 4})$ & $\%$ \\
\hline Age & 2 & \\
$\quad<20$ years & 15 & 8.3 \\
20-29 years & 7 & 62.5 \\
$\quad$ 30 years & & 29.2 \\
Color & 19 & \\
$\quad$ White & 3 & 79.2 \\
Mixed race & 2 & 12.5 \\
$\quad$ Black & & 8.3 \\
Marital status & 22 & \\
Married or living with partner & & 91.7 \\
Level of education & 2 & \\
Higher education complete & 6 & 8.3 \\
Higher education incomplete & 7 & 25.0 \\
Secondary education complete & 3 & 29.2 \\
Secondary education incomplete & 4 & 12.5 \\
Primary education complete & 2 & 16.7 \\
Primary education incomplete & & 8.3 \\
Occupation & 13 & \\
Fixed employment & 6 & 54.2 \\
Student & 4 & 25.0 \\
Housewife & 1 & 16.7 \\
Self-employed & & 4.1 \\
Per capital monthly family income & 6 & \\
Up to half a minimum salary & 8 & 25.0 \\
Between half and one minimum salary & 9 & 33.3 \\
Between one and two minimum salaries & 1 & 37.5 \\
Over five minimum salaries & & 4.2 \\
\hline
\end{tabular}

Source: Research data, 2013

a third of them had incomplete or complete higher education. When analyzing per capital family income, the data showed that the large majority of puerperal women had a low family income.

In the sample studied, the majority of puerperal women had a fixed income. Furthermore, some of the employed pregnant women had their main meals outside of the home, with the weight gain for such women during pregnancy from 13 to $20 \mathrm{~kg}$.

When questioned about the presence of a feeling of anxiety or stress during the pregnancy, the response was positive for $79.2 \%(n=19)$ and $75.0 \%(n=18)$ of the puerperal women, respectively, i.e. a large part of the participants felt anxious or stressed during the pregnancy. The sources of stress were predominantly family and conjugal aspects. Furthermore, for the majority of puerperal women $(58.3 \% ; n=14)$ there was a good acceptance of their body image.

In relation to physical activity during the gestational period, $70.8 \%(n=17)$ of the puerperal women stated they did not practice regular physical activity, with sedentary lifestyles prevailing among participants. In relation to monitoring during pregnancy, $83.3 \%(n=20)$ of the puerperal women had more than six prenatal consultations and $62.5 \%$ $(n=15)$ received nutritional guidance.

In relation to the use of drugs during pregnancy, $16.7 \%(n=4)$ of the puerperal women used tobacco; 
Table 2 - Characteristics in relation to nutritional state and gestation - Porto Alegre, 2013.

\begin{tabular}{lcc}
\hline \multicolumn{1}{c}{ Variables } & $\mathbf{n}(\mathbf{2 4})$ & \% \\
\hline $\begin{array}{l}\text { Number of pregnancies } \\
\quad \text { Multiparous }\end{array}$ & 14 & 58.3 \\
Planned pregnancy & 10 & 41.7 \\
$\quad$ Yes & & \\
Pre-gestational nutritional state & 11 & 45.8 \\
$\quad$ Eutrophic & 2 & 8.3 \\
$\quad$ Underweight & 9 & 37.5 \\
$\quad$ Overweight & 2 & 8.3 \\
$\quad$ Obese & & \\
Gestational weight gain & 15 & 62.5 \\
$\quad$ Excessive & 6 & 25.0 \\
$\quad$ Adequate & 3 & 12.5 \\
$\quad$ Insufficient & & \\
Nutritional state upon hospital admission & 9 & 37.5 \\
$\quad$ Overweight & 7 & 29.2 \\
Obese & 5 & 20.8 \\
$\quad$ Eutrophic & 3 & 12.5 \\
$\quad$ Underweight & & \\
\hline
\end{tabular}

Source: Research data, 2013.

$8.3 \%(n=2)$ took alcoholic drinks; $12.5 \%(n=3)$ used illegal drugs (cannabis and/or cocaine and/or crack). When specifically analyzing the use of licit and illicit drugs during pregnancy, it was noted that despite the pregnant woman obtaining an adequate weight gain, the newborn was classified as PIG.

The data showed that, in general, the average weight gain during the gestational period was 14.3 $(\mathrm{DP}=5.0) \mathrm{kg}$, varying between $3.0 \mathrm{~kg}$ (minimum) and $24.6 \mathrm{~kg}$ (maximum). Despite this, when analyzing each case individually, it was shown that more than half of the sample studied presented some nutritional deviation. In relation to weight gain, it was noted that the majority of the sample had an inadequate weight gain.

In the study, $66.7 \%(n=16)$ of the women had a vaginal birth and $33.3 \%(n=8)$ were submitted to a cesarean, owing to reasons related to cephalopelvic disproportion, the wishes of the mother and presentation of anomalies. It is worth reiterating that the women submitted to cesarean presented an adequate BMI and average weight gain of 15 $\mathrm{kg}$ (i.e. within the recommended eutrophic limits).

In relation to the newborns, $54.2 \%(n=13)$ were of the female sex; $79.2 \%(n=19)$ were adequate for gestational age (AIG); followed by $8.3 \%(n=2)$ that were small for gestational age (PIG) and $12.5 \%$ $(n=3)$ that were large for gestational age (GIG). The average stature at birth was $49.6(\mathrm{DP}=2.3)$ $\mathrm{cm}$, with a variation between 45 (minimum) and 53 (maximum) $\mathrm{cm}$.

Considering the maternal weight gain, the average weight of the newborns was $3409 \mathrm{~g}$ for pregnant women with excessive weight gain, 3329 $\mathrm{g}$ for adequate weight gain and $3595 \mathrm{~g}$ for weight gain lower than recommended. The results show that GIG newborns came from pregnant women with excessive weight gain during the gestational period or that were overweight (considering the average upon hospital admission). Furthermore, it is important to highlight that one of the cases of malnutrition during the pre-gestational period resulted in an underweight newborn (PIG).

\section{DISCUSSION}

The results relating to characterization of the sample of the present study come close to the findings in the literature consulted, given that in a previous study ${ }^{(12)}$, the average age of the preg- 
nant women was $25(\mathrm{DP}=3.8)$ years, with a higher prevalence of multiparous women $(59,9 \%)$. It is important to reiterate that maternal age can influence the pregnancy-puerperal process in relation to the meaning of the pregnancy. In accordance with the age, maturity and the life context, women experience maternity in an individual manner, reflecting positively or negatively on self-care.

The presence of a partner may mean better psychosocial support during pregnancy, influencing gains in gestational weight ${ }^{(13)}$. According to the literature consulted ${ }^{(13)}$, the pregnant women that did not have a companion gained an average of $2.3 \mathrm{~kg}$ more in relation to pregnant women living with partners.

According to data from the Brazilian Institute of Geography and Statistics ${ }^{(14)}$, in the year 2009 the color white represented a prevalence of $81.3 \%$ in the population resident in Porto Alegre - RS. In accordance with the literature consulted ${ }^{(15)}$, the ethnic characteristics of the population in the south of the country are influenced by demographic aspects of large scale European colonization. Therefore, this fact may explain the high prevalence of the color white in the sample studied.

Also according to data from the $\mathrm{IBGE}^{(14)}$, the level of education of the population in Porto Alegre presented a percentage of $22.9 \%$ for the 11 to 14 years of study category in 2009. It can be seen that the prevalence of this category has increased from the year 2001 to 2009. This data shows an increasing evolution in relation to the level of education of the population in the said city.

In this context, a previous study ${ }^{(19)}$ concluded that pregnant women with a higher level of education gain $1.9 \mathrm{~kg}$ more in relation to those with a lower education level. However, a study conducted in Canada ${ }^{(16)}$ showed that women with a level of education below average, associated with social and demographic factors (such as family income and age) had higher changes of gaining above the recommended level.

It is important to reiterate that eating away from home may be related to excess and unbalanced alimentation in relation to the composition and quality of nutrients, leading to exaggerated food consumption and consequent excessive weight gain.

The findings related to family income in the sample studied coincides with the national scenario which in 2009 presented an average per capita family income of $27.2 \%$ with income between half and one minimum salary ${ }^{(14)}$. For some authors ${ }^{(16-17)}$, women with low income and a low level of education have a higher risk of excessive weight gain during pregnancy. In this sense, the socioeconomic characteristics may contribute to unequal access to health services and consequently the basic information required for better outcomes in the reproductive period.

In the present study, in relation to the emotional aspects during pregnancy, a high prevalence of feelings such as anxiety and stress was identified. However, pregnancy is a period in which large physiological and psychological changes take place, with a lot of intense feelings. Anxiety is a recurrent emotional aspect during all stages of the pregnancy ${ }^{(7)}$. A study conducted on 30 pregnant women showed that $93 \%$ of them presented stress during the gestational period, which was usually related to aspects intrinsic to the pregnancy itself, day to day problems, economic and family factors ${ }^{(18)}$.

In relation to physical activity, a sedentary lifestyle was the most prevalent finding among the women studied. According to the literature consulted, the realization of physical activity respecting the specific principles of the pregnancy may provide beneficial maternal and fetal results ${ }^{(7)}$. The fact that a greater prevalence of sedentary participants was found could be an important issue to be worked on by health professionals when providing care to pregnant women.

Another important characteristics related to lifestyle during pregnancy was the use of licit or illicit drugs in more than a third of the sample in the present study. In puerperal women attended to at the General Hospital of Fortaleza, smoking was present in $11.3 \%$ of pregnancies and the ingestion of alcoholic drinks in $16 \%$. It was not possible to make an association with statistical significance between the consumption of alcohol and smoking during the pregnancy and the presence of fetal malformations ${ }^{(19)}$. Regardless of the results referenced, stopping smoking is as important as abstaining from illicit drugs to avoid negative results in pregnancy.

Furthermore, in the present study there was one case of the use of licit and illicit drugs during pregnancy in which the newborn was classified as PIG. It is important to reiterate that children classified as PIG at birth require special attention 
from the health services and should be considered as children at nutritional risk.

For the pregnancy to run safely it is necessary for the prenatal monitoring to include the prevention, promotion of health and treatment of problems that could occur during the gestational period. Therefore, it is recommended to undertake a minimum of six prenatal consultations, preferably one in the first trimester, two in the second and three in the third trimester of the pregnancy ${ }^{(7)}$.

In this context, the lower number of prenatal consultations is a risk factor for insufficient weight gain but a protective factor for excessive weight gain. This finding is related to the fact that prenatal healthcare is focused on the prevention of insufficient weight gain in order to prevent newborns with low birth weight, thereby discouraging restrictive diets and weight loss during pregnancy ${ }^{(5)}$.

In relation to the outcome of the gestational period, both insufficient and excess weight gain may have repercussions on the nutritional state of the newborn. In this context, women that start the pregnancy undernourished or that present insufficient weight gain have a higher risk of having underweight newborns ${ }^{(20)}$. On the other hand, the children of overweight/obese mothers at the start of the pregnancy or with higher weight gain tend towards macrosomia ${ }^{(3,20)}$.

\section{CONCLUSIONS}

In this study, in general, the women were characterized as young, multiparous, with low family income and a secondary and higher education level. Furthermore, during pregnancy, they received nutritional guidance and prenatal assistance in accordance with the recommendations of the Ministry of Health. Despite this, a large part of puerperal women present some pre-gestational nutritional deviation or inadequate weight gain during the pregnancy.

In turn, the majority of newborns were characterized as AIG. However, considering the cases of GIG newborns, it was noted that the pregnant women gained excessive weight during the pregnancy or were overweight (considering the average upon hospital admission). Furthermore, once case of malnutrition during the gestational period results in a PIG newborn, corroborating the literature consulted.
As such, the findings suggest that health professionals should be aware of both nutritional deviations in the pre-gestational period as well as inadequate weight gain during the pregnancy, making it necessary for this aspect to be an important issue for prevention strategies in the health women of reproductive age, with the intention of avoiding possible harm to maternal and fetal health.

It can been noted that there are few Brazilian studies that cover the issue in question, which makes it difficult to verify the nutritional situation of Brazilian pregnant women and, consequently, the lack of reference to professional conduct in relation to pregnant women at nutritional risk. This study presents results based on a small sample, providing merely a descriptive analysis and limitation the generalization of the findings. Therefore, future studies with a representative sample could seek an association between the variables, contributing further to the clinical practice of health professionals.

\section{REFERENCES}

1 Gonzalez DA, Nazmi A, Victora CG. Growth from birth to adulthood and abdominal obesity in a Brazilian birth cohort. Int J Obes. 2010;34:195-202.

2 Ministério da Saúde (BR) [Internet]. Pesquisa Nacional de Demografia e Saúde da Criança e da Mulher. Saúde Nutricional. Saúde e estado nutricional de crianças menores de cinco anos. PNDS-2006 [citado 2012 maio 03]. Available in: http://bvsms.saude.gov. br/bvs/pnds/saude_nutricional.php.

3 Deierlein AL, Siega-Riz AM, Adair LS, Herring AH. Effects of prepregnancy body mass index and gestational weight gain on infant anthropometric outcomes. J. Pediatr. 2011;158(2):221-6.

4 Schack-Nielsen L, Michaelsen KF, Gamborg M, Mortensen EL, Sorensen T. Gestational weight gain in relation to offspring body mass index and obesity from infancy through adulthood. Int J Obes. 2010;34:67-74.

5 Drehmer M, Camey S, Schmidt ML, Olinto MT, Giacomello A, Buss C, et al. Socieconomic, demographic and nutritional factors associated with maternal weight gain in general practices in Southern Brazil. Cad Saúde Pública. 2010;26(5):1024-34.

6 Institute of Medicine of the National Academies (US). Weight gain during pregnancy: reexamining 
the guidelines. Report brief. May 2009 [citado em 2012 maio 17]. Available in: http://www.iom.edu/ / media/Files/Report Files/2009/Weight-Gain-During-Pregnancy-Reexamining-the-Guidelines/ Report Brief - Weight Gain During Pregnancy.pdf

7 Ministério da Saúde (BR), Secretaria de Atenção à Saúde, Departamento de Ações Programáticas Estratégicas, Área Técnica de Saúde da Mulher. Pré-natal e puerpério: atenção qualificada e humanizada. Brasília: Ministério da Saúde; 2006.

8 Beyerlein A, Nehring I, Rzehak P, Heinrich J, MüllerMJ, Plachta-Danielzik S, et al. Gestational weight gain and body mass index in children: results from three German cohort studies. PLoS ONE. 2012;7(3):e-33205.

9 Guelinckx I, Devlieger R, Vansant G. Maternal obesity: pregnancy complications, gestational weight gain and nutrition. Obes Rev. 2008;9(2):140-50.

10 Ministério da Saúde (BR), Secretaria de Assistência à Saúde, Coordenação materno-infantil. Manual de assistência ao recém-nascido. Brasília: 1994.

11 Ministério da Saúde (BR), Conselho Nacional de Saúde. Resolução 466/2012 [citado 2013 jul 22]. Available in: http://conselho.saude.gov.br/resolucoes/2012/Reso466.pdf

12 Lima GSP, Sampaio HAC. Influência de fatores obstétricos, socioeconômicos e nutricionais da gestante sobre o peso do recém-nascido: estudo realizado em uma maternidade em Teresina, Piauí. Rev Bras Saúde Matern Infant. 2004;4(3):253-61.
13 Konno SC, Benício MHD, Barros AJD. Fatores associados à evolução ponderal de gestantes: uma análise multinível. Rev Saúde Pública. 2007;41(6):995-1002.

14 Instituto Brasileiro de Geografia e Estatística. Pesquisa Nacional por Amostra de Domicílio 2001-2009 [citado 2013 maio 14]. Available in: http://seriesestatisticas.ibge.gov.br/series.aspx?vcodigo=ECE370.

15 Seyferth G. Colonização, imigração e a questão racial no Brasil. Rev USP. 2002;53:1 17-49.

16 Kowal C, Kuk J, Tamim H. Characteristics of weight gain in pregnancy among Canadian women. Matern Child Health J. 2012;16(3):668-76.

17 Castro MBT; Kac G, Sichieri R. Determinantes nutricionais e sócio-demográficos da variação de peso no pós-parto: uma revisão da literatura. Rev Bras Saúde Matern Infant. 2009;9(2):1235-7.

18 Segato L, Andrade A, Vasconcellos DIC, Matias TS, Rolim MKS. Ocorrência e controle do estresse em gestantes sedentárias e fisicamente ativas. Rev Educ Fís UEM. 2009;20(1):121-9.

19 Rocha RS, Bezerra SC, Lima JWO, Costa FS. Consumo de medicamentos, álcool e fumo na gestação e avaliação dos riscos teratogênicos. Rev. Gaúcha Enferm. 2013; 34(2):37-45.

20 Gonçalves CV, Mendoza-Sassi RA, Cesar JA, Castro $\mathrm{NB}$, Bortolomedi AP. Índice de massa corporal e ganho de peso gestacional como fatores preditores de complicações e do desfecho da gravidez. Rev Bras Ginecol Obstet. 2012;34(7):304-9.

\author{
Author's address / Endereço do autor / \\ Dirección del autor \\ Márcia Koja Breigeiron \\ Escola de Enfermagem da Universidade Federal do \\ Rio Grande do Sul \\ Rua São Manoel, 963, Rio Branco \\ 90620-1 10, Porto Alegre, RS \\ E-mail: mbreigeiron@gmail.com
}

Received: 24.09.2013

Approved: 17.01.2014 